\title{
Evaluation of Antipsychotic Activity of Ethanolic Bark Extract of Myrica esculenta in Rats
}

\author{
Biswash Sapkota $^{1 *}$, Ankit Acharya ${ }^{1}$, Bishal Dangi ${ }^{2}$, Annegowda HV ${ }^{1}$ \\ ${ }^{1}$ Sri Adichunchanagiri College of Pharmacy, B.G. Nagar-571448, India \\ ${ }^{2}$ Mallige College of Pharmacy, Bangalore, India
}

\begin{abstract}
The antipsychotic properties of Myrica esculenta stem bark were evaluated. The stem bark was collected, shade dried, and pulverized. Extraction was carried out with $70 \%$ ethanol by occasional shaking. Preliminary phytochemical screening of the extract was investigated in this study. Antipsychotic activity was evaluated against apomorphine-induced stereotypy using cook's pole climbing apparatus and haloperidol-induced catalepsy models. Bioamine determination of noradrenaline and dopamine was also performed. The extract contains phytochemicals, including glycosides, flavonoids, volatile oils, proteins, saponins, phenolics, and tannins. The result showed decreased apomorphine-induced stereotyped behavior. This study reported significant dose-dependent potentiation of haloperidol-induced catalepsy in rats and a longer time needed by the rat to climb the pole in a dose-dependent manner. Also, it significantly decreased brain dopamine and noradrenaline level. The ethanolic extract of $M$. esculenta exhibited significant antipsychotic activity in rats. Further neurochemical investigation is needed to explore the plant drug's mechanism of action regarding anti-dopaminergic functions and establish the plant as an antipsychotic agent.
\end{abstract}

Keywords: apomorphine; haloperidol; stereotypy; catalepsy; Myrica esculenta

*corresponding author

Email:merobiswash8@gmail.com

\section{INTRODUCTION}

The traditional system of medication has given knowledge for the discovery of new valuable drugs. The modern and advent techniques of drug screening and drug development of traditional medicine have values and importance in many people. In the world, $80 \%$ of the population still use traditional medicine as their primary source of medication (Surveswaran et al., 2007). Due to the modern isolation techniques and pharmacological testing procedures, new plant drugs get their way to the modern medication system (Jain, Jain, and Shete, 2010). Myrica esculenta Buch - Ham. (Family: Myricaceae) is a traditional plant used in ayurvedic medicine for its catarrhal fever, cough, throat infection, asthma, urinary discharges, bronchitis, psychiatric disorder anemia, cholera, ulcers, and in treatments of various disease (Bhatt, Rawal, and Dhar, 2000). In the present study, an attempt has been made to explore the psychoactive potential of the ethanolic extract of M. esculenta in apomorphine-induced stereotyped behavior, cook's pole climbing apparatus, and haloperidol-induced catalepsy models. Bioamine determination of noradrenaline and dopamine was also performed.

Myrica esculenta Buch - Ham. (Fam., Myricaceae) Syn., M. nagi Hook. F., commonly known as Kaiphala or Katphala is an evergreen dioecious tree distributed in the subtropical Himalayas. It is distributed in India, Nepal, China, Pakistan, and Malaysia Islands. The plant is commonly found in the outer Himalayan region at an altitude starting from about $900 \mathrm{~m}$ up to $2,100 \mathrm{~m}$. It is a medium to a large woody, evergreen, dioecious tree, attains a height of 12 to 15 meters (Sood and Shri, 2018). Leaves are lanceolate, $9 \mathrm{~cm}$ long, $3 \mathrm{~cm}$ broad, lower surface-pale green, upper surface-dark green. Generally, leaves are crowded towards the end of branches. The bark is grey to brownish-grey, inner surface dark brown in color and smooth, fracture hard, and tastes bitter. Flowers are minute, unisexual and glandular, sessile, solitary, and bracteate; sepals and petals, either absent or not visible; inflorescence, a catkin, $4.2 \mathrm{~cm}$ long, axillary, bearing about 25 flowers; only a thread-like style visible with the unaided eye. Fruits are drupe, ellipsoid, or ovoid-shaped, in length $0.7-1.0 \mathrm{~cm}, 0.5-0.7 \mathrm{~cm}$ wide dark brown colored. Seeds are ovoid $0.6 \mathrm{~cm}$ long and $0.3 \mathrm{~cm}$ wide. The seed's surface is very smooth, light brown in color, and oily in the test. The plant prefers light (sandy) and medium (loamy) soils and requires well-drained soil with 250 - $205 \mathrm{~cm}$ rainfall (Kabra et al., 2019a; Sood and Shri, 2018). A variety of constituents has been isolated from M. esculenta, and their structures were elucidated. They belong to different classes such as glycosides, flavonoids, volatile oils, proteins, saponins, phenolics, and tannins (Srivastava et al., 2016). 


\section{METHODS}

\section{Collection of Plant Material}

The stem bark of M. esculenta was collected from the western hills of Nepal. The plant was identified and authenticated by Dr. N.M. Ganesh Babu, a botanist at FRLHT (Foundation for Revitalisation of Local Health Traditions) Jarakabande Kaval, post Attur, Yehalanka, Bangaluru (560106). A herbarium specimen of the plant was prepared and kept at the pharmacognosy laboratory of college for future references.

\section{Extraction}

Dried and powdered stem bark (100 g) was extracted with $70 \%$ ethanol with occasional shaking for 24 hours.

\section{Phytochemical Analysis}

Phytochemical analysis was carried out to test its chemical constituents. All the chemicals used for testing were of analytical grade, and procedures were based on the standards protocols (Sapkota and Jain, 2020).

\section{Animals}

Male albino rats (150-200 g) were used in this study. All the rats were placed in an animal house with room temperature $\left(24{ }^{\circ} \mathrm{C} \pm 2\right)$ and humidity $(60-70 \%)$. The animal house was cleaned occasionally. Food with ad libitum of water was supplied to all animals. The experimental procedure was performed as per the international ethics committee guideline only after the approval from the Institutional Animal Ethics Committee (IAEC) (Sahoo et al., 2016).

\section{Pharmacological Studies}

1. Apomorphine-induced stereotypy in rats (Erbaş et al., 2013)

2. Haloperidol-iduced catalepsy (Nishchal et al., 2014)

3. Pole climb avoidance in rats (Madhav, 2015)

\section{Bioamine Estimation in Rat Brain}

\section{Collection of brain sample}

Rats were sacrificed by decapitation process. The brain was collected rapidly, washed properly, made free from blood, and stored at $-20^{\circ} \mathrm{C}$. Thus, the weight of the brain was measured for amine determination. After thawing, homogenization of the brain was done with ice-cold 0.01 $\mathrm{N} \mathrm{HCl}$ and $0.1 \mathrm{ml} \mathrm{10 \%} \mathrm{EDTA.} \mathrm{Homogenate} \mathrm{was} \mathrm{mixed}$ properly by shaking with $25 \mathrm{ml} \mathrm{n}$-butanol and $4 \mathrm{~g} \mathrm{NaCl}$. Finally, the mixture was centrifuged and kept at room temperature for $20 \mathrm{~min}$. Then, $24 \mathrm{ml} \mathrm{n}$-butanol, $40 \mathrm{ml}$ $\mathrm{n}$-heptane, and $1.5 \mathrm{ml} 0.5 \mathrm{M}$ phosphate buffer $(p \mathrm{H} 7.3)$ were added. The mixture was shaken for $10 \mathrm{~min}$ and settled for $10 \mathrm{~min}$. After that, $1.5 \mathrm{ml}$ phosphate buffer layer was taken. It was acidified to $\mathrm{pH} 3.5$ to 4.0 with $3 \mathrm{~N} \mathrm{HCl}$. Peroxide free ether $(20 \mathrm{ml})$ was added to it and shaken for $10 \mathrm{~min}$. Aqueous acid layer $(0.5 \mathrm{ml})$ was taken for fluorometric estimation of noradrenaline and dopamine, etc., following Welch and Welch's method.

1. Estimation of noradrenaline (Brownlee and Spriggs, 1965; Welch and Welch 1969)

2. Estimation of dopamine (Brownlee and Spriggs, 1965; Welch and Welch, 1969)

\section{Statistical Analysis}

Results were expressed as mean \pm SEM, $(n=6)$. Statistical analyses were performed with one -way analysis of variance (ANOVA) followed by Tukey Multiple Comparison Test by using Graph Pad Prism. A $\mathrm{P}$-value less than 0.05 was considered to be statistically significant.

\section{RESULTS}

\section{Phytochemical Investigation in The Bark of $M$.} esculenta

Phytochemical screening was performed in this study. It showed various phytochemicals like carbohydrates, saponins, flavonoids, phenolics, glycosides, proteins, volatile oils, tannins, and mucilage. It also indicated that alkaloids, fat and fatty acids, phytosterols, and flavone glycosides were absent. The details of the phytochemical screening are given in Table 1.

Table 1: Phytoconstituents present in the bark extract of M. esculenta

\begin{tabular}{lll}
\hline No & Phytoconstituents & Result \\
\hline $\mathbf{1}$ & Carbohydrates & + \\
$\mathbf{2}$ & Alkaloids & - \\
$\mathbf{3}$ & Saponins & + \\
$\mathbf{4}$ & Flavonoids & + \\
$\mathbf{5}$ & Phenolics & + \\
$\mathbf{6}$ & Fat and Fatty acids & - \\
$\mathbf{7}$ & Glycosides & + \\
$\mathbf{8}$ & Proteins & + \\
$\mathbf{9}$ & Volatile oils & + \\
$\mathbf{1 0}$ & Tannins & + \\
$\mathbf{1 1}$ & Phytosterols & - \\
$\mathbf{1 2}$ & Mucilage & + \\
$\mathbf{1 3}$ & Flavone glycosides & - \\
\hline & &
\end{tabular}

(+) indicates presence and (-) indicates absence of Phytochemicals 
Table 2: Effect of ethanolic extract of M. esculenta on apomorphine-induced stereotyped behavior

\begin{tabular}{|c|c|c|c|c|c|c|c|c|c|}
\hline \multirow{2}{*}{ Treatment } & \multicolumn{9}{|c|}{ Stereotype score (mean \pm S.E.M.) at } \\
\hline & $10 \mathrm{~min}$ & $20 \mathrm{~min}$ & $30 \mathrm{~min}$ & $40 \mathrm{~min}$ & $50 \mathrm{~min}$ & $60 \mathrm{~min}$ & $70 \mathrm{~min}$ & $80 \mathrm{~min}$ & $90 \mathrm{~min}$ \\
\hline Normal & $3.34 \pm 0.32$ & $4.68 \pm 0.23$ & $4.73 \pm 0.27$ & $5.16 \pm 0.41$ & $4.61 \pm 0.71$ & $4.21 \pm 0.67$ & $2.79 \pm 0.61$ & $3.11 \pm 0.58$ & $2.41 \pm 0.31$ \\
\hline HAL & $0.61 \pm 0.2^{9 *}$ & $1.12 \pm 0.41^{* * *}$ & $1.42 \pm 0.19^{* * *}$ & $0.86 \pm 0.54^{* * *}$ & $0.32 \pm 0.22^{* * *}$ & $0.69 \pm 0.31^{* *}$ & $1.26 \pm 0.19^{*}$ & $1.67 \pm 0.38^{* *}$ & $0.32 \pm 0.22^{*}$ \\
\hline ME 200 & $2.21 \pm 0.48$ & $2.85 \pm 0.40^{* *}$ & $2.65 \pm 0.61^{* *}$ & $2.49 \pm 0.56^{* *}$ & $1.47 \pm 0.22^{* *}$ & $1.84 \pm 0.40^{*}$ & $2.35 \pm 0.76$ & $2.05 \pm 0.41$ & $2.72 \pm 0.58$ \\
\hline ME 400 & $1.94 \pm 0.30$ & $2.67 \pm 0.21^{* * *}$ & $2.30 \pm 0.42^{* * *}$ & $1.17 \pm 0.30^{* * *}$ & $1.02 \pm 0.26^{* * *}$ & $1.34 \pm 0.42^{*}$ & $0.69 \pm 0.21$ & $0.79 \pm 0.31^{* *}$ & $1.32 \pm 0.49$ \\
\hline
\end{tabular}

(Values are expressed in mean \pm S.E.M., where HAL $=$ Haloperidol, ME $=$ Myrica esculenta, $n=6 .{ }^{*} P<0.05^{* *} P<0.01{ }^{* * * *} P<0.001$; compared with vehicle treated group)

Table 3: Effect of ethanolic extract of M. esculenta on haloperidol-induced catalepsy

\begin{tabular}{lllllll}
\hline \multirow{2}{*}{ Treatment } & \multicolumn{5}{c}{ Catalepsy score (mean \pm S.E.M.) at } \\
\cline { 2 - 7 } & $\mathbf{1 5} \mathbf{~ m i n}$ & $\mathbf{3 0} \mathbf{~} \mathbf{m}$ & $\mathbf{4 5} \mathbf{~ m i n}$ & $\mathbf{6 0 ~} \mathbf{~ i n}$ & $\mathbf{7 5} \mathbf{~ m i n}$ & $\mathbf{9 0} \mathbf{~ m i n}$ \\
\hline Normal & $0 \pm 0$ & $0 \pm 0$ & $0 \pm 0$ & $0 \pm 0$ & $0 \pm 0$ & $0 \pm 0$ \\
HAL & $54.25 \pm 1.95$ & $52.95 \pm 1.60$ & $54.83 \pm 2.13$ & $53.93 \pm 2.53$ & $56.45 \pm 1.08$ & $58.12 \pm 0.57$ \\
ME 200 + HAL & $55.48 \pm 1.08$ & $54.62 \pm 0.95$ & $57.22 \pm 1.73$ & $58.60 \pm 1.74$ & $58.18 \pm 1.18$ & $58.90 \pm 1.11$ \\
ME 400 + HAL & $59.28 \pm 1.53$ & $59.07 \pm 0.67^{* *}$ & $64.02 \pm 2.01^{*}$ & $62.75 \pm 1.37^{*}$ & $61.38 \pm 1.51^{*}$ & $61.75 \pm 1.97$ \\
\hline
\end{tabular}

(Values are expressed in mean \pm S.E.M., where $H A L=$ Haloperidol, $M E=$ Myrica esculenta, $n=6 .{ }^{*} P<0.05$; compared with vehicle treated group) 
Table 4: Effect of ethanolic extract of M. esculenta on condition avoidance response

\begin{tabular}{llll}
\hline No. & Treatment & No. of Time Escaped & $\begin{array}{l}\text { \% Reduction in No. Of } \\
\text { Times Escaped }\end{array}$ \\
\hline 1. & Control & $16 \pm 1.97$ & 0 \\
2. & HAL & $9 \pm 1.23$ & 43.75 \\
3. & ME $(200 \mathrm{mg} / \mathrm{kg})$ & $12 \pm 2.64$ & 25 \\
4. & ME $(400 \mathrm{mg} / \mathrm{kg})$ & $11 \pm 2.97$ & 31.25 \\
\hline
\end{tabular}

(Values are expressed in mean \pm S.E.M, where $M E=$ Myrica esculenta, HAL $=$ Haloperidol)

\section{Apomorphine-Induced Stereotyped Behaviors}

Animals pre-treated with of $200 \mathrm{mg} / \mathrm{kg}$ dose of extract produced significant $(\mathrm{P}<0.05$ and $\mathrm{P}<0.01)$ reduction in stereotyped score at 20,30, 40, 50. and $60 \mathrm{~min}$ time interval as compared to the vehicle-treated animals. A higher dose of $M$. esculenta $(400 \mathrm{mg} / \mathrm{kg})$ produced a significant $(\mathrm{P}<0.001)$ reduction in the stereotyped score at $10-50$ min time intervals. The effect is shown in Table 2.

\section{Haloperidol-Induced Catalepsy}

M. esculenta extract-treated rat did not show different effects and appeared the same as the vehicle-treated animals, so it did not induce catalepsy in rat. The cataleptic effect produced by haloperidol (1 mg/kg ip) was not affected by extract of $200 \mathrm{mg} / \mathrm{kg}$ dose while $400 \mathrm{mg} / \mathrm{kg}$ produce significant effect and $(\mathrm{P}<0.05$ and $\mathrm{P}<0.01)$ potentiate the cataleptic effect of haloperidol at $15,30,45,60,75$ and 90 min time intervals. The effects are shown in Table 3.

\section{Pole Climbing Avoidance in Rats}

All the groups (i.e. HAL $(1 \mathrm{mg} / \mathrm{kg})=9 \pm 1.23, M$. esculenta $(200 \mathrm{mg} / \mathrm{kg})=12 \pm 2.64$ and M. esculenta $(400$ $\mathrm{mg} / \mathrm{kg})=11 \pm 2.97)$ significantly $(\mathrm{P}<0.05)$ decreased the escape response compared to the vehicle treated group (i.e. $16 \pm 1.97)$. Haloperidol $(1 \mathrm{mg} / \mathrm{kg})$ reduced the escape response by almost $43 \%$, M. esculenta $(200 \mathrm{mg} / \mathrm{kg})$ by $25 \%$ and $M$. esculenta $(400 \mathrm{mg} / \mathrm{kg}$ ) by $25 \%$. It is well depicted in Table 4.

\section{Bio Amine Estimation}

\section{Nor adrenaline}

The present spectrophotometric analysis showed a decrease in the NA level in all test groups compared to the control group. M. esculenta $200 \mathrm{mg} / \mathrm{kg}, 400 \mathrm{mg} / \mathrm{kg}$, and haloperidol pretreatment in rats exhibited a significant reduction in brain noradrenaline level compared to control group. The details are shown in Table 5.

\section{Dopamine}

The present spectrophotometric analysis showed a reduction in the dopamine level in all test groups as compared to the control group. M. esculenta $200 \mathrm{mg} / \mathrm{kg}$,
Table 5: Noradrenaline (ng/mg) level in rat brain

\begin{tabular}{|c|c|c|}
\hline No & Group & $\begin{array}{l}\text { Noradrenaline in }(\mathrm{ng} / \mathrm{mg}) \\
\text { Mean } \pm \text { SEM }\end{array}$ \\
\hline 1. & Control & $589.70 \pm 28.44$ \\
\hline 2. & HAL & $541.40 \pm 30.54 * * *$ \\
\hline 3. & ME (200 mg/kg) & $579.14 \pm 28.26^{*}$ \\
\hline 4. & ME (400 mg/kg) & $563.23 \pm 27.13 * * *$ \\
\hline
\end{tabular}

Table 6: Dopamine level (ng/mg) in rat brain

\begin{tabular}{lll}
\hline No & Group & $\begin{array}{l}\text { Dopamine in }(\mathbf{n g} / \mathbf{m g}) \\
\text { Mean } \pm \text { SEM }\end{array}$ \\
\hline 1. & Control & $2364 \pm 43.34$ \\
2. & HAL & $2015 \pm 146.40 * * *$ \\
3. & ME $(200 \mathrm{mg} / \mathrm{kg})$ & $2296 \pm 186.30^{*}$ \\
4. & ME $(400 \mathrm{mg} / \mathrm{kg})$ & $2065 \pm 170.10^{* * *}$ \\
\hline
\end{tabular}

(Values are expressed in mean \pm S.E.M., where $* P<0.05 * * P<0.01$ $* * * P<0.001$; compared with vehicle treated group)

$400 \mathrm{mg} / \mathrm{kg}$, and haloperidol pretreat M. esculenta in rats exhibited significant reduction in brain dopamine level $(\mathrm{P}<0.05, \mathrm{P}<0.001$ and $\mathrm{P}<0.001$, respectively) compared to control group.

\section{DISCUSSION}

In the present study, the antipsychotic effects of the hydroalcoholic extract of $M$. esculenta bark were studied in several behavioral animal models to evaluate their possible psychotropic activity. The present investigation results showed that the ethanolic extract of M. esculenta bark has some potent antipsychotic activity.

Firstly, the extract was tested in apomorphine-induced stereotyped behavior in rats, which is the classical model for antipsychotic effects (Protais, Costentin, and Schwartz, 1976). In this model, apomorphine, a non-selective dopamine agonist, induces stereotyped behavior such as locomotor hyperactivity, climbing, stereotyped grooming, licking, and gnawing. The ability 
of test agents to inhibit these behaviors is a measure of its antipsychotic effect (Protais, Costentin, and Schwartz, 1976). This model is largely based on the dopamine theory of schizophrenia. In this study, as expected, apomorphine-induced stereotypy behavior was inhibited by both the extract and the reference drug, haloperidol. Experimental studies have shown that phytochemicals, particularly flavonoids and vitamins, present in $M$. esculenta are important antioxidants and superoxide scavengers. The antioxidant activity of $M$. esculenta may be responsible for its beneficial antipsychotic action (Srivastava et al., 2016).

Accordingly, the extract was tested in a haloperidolinduced cataleptic model in rats. In this model, haloperidol, a typical neuroleptic agent, induced a cataleptic state in rodents, which tested the extrapyramidal side effects of antipsychotic agents. Haloperidol is a well-known neuroleptic, primarily acting as a D2 receptor antagonist in the mesolimbic and mesocortical pathways. Due to its non-selective action, it also produces blockade of postsynaptic D2 receptors in the nigrostriatal pathway leading to the development of extrapyramidal side effects in humans and catalepsy in animals (Sanberg, 1980). Several other neurotransmitters such as acetylcholine, serotonin, angiotensin, adenosine, or opioids have also been implicated in the catalepsy induced by neuroleptic agents (Polydoro et al., 2004). Along with neurotransmitters in catalepsy, reactive oxygen species have also been proposed to play a role in haloperidolinduced toxicity (Polydoro et al., 2004). Several earlier behavioral studies have demonstrated dopamine facilitator activity and the antioxidant properties of $M$. esculenta, and it has been claimed to give remarkable protection against lipid peroxidation (Kabra, et al., 2019b; Kabra, et al., 2019c). Since reactive oxygen species have been implicated in haloperidol-induced toxicity, it can be safely assumed that the antioxidant property of $M$. esculenta may contribute towards its anticataleptic activity too.

Similarly, pole-climb avoidance is often used for differentiating neuroleptic activity and sedatives property in rats. Administration of M. esculenta for 30 successive days in different concentrations significantly $(\mathrm{P}<0.05$, $\mathrm{P}<0.01)$ delayed the latency time taken by the animals to climb the pole in the Passive Avoidance Paradigm.

\section{CONCLUSION}

The present study demonstrates that M. esculenta has a protective effect against apomorphine-induced stereotypy, haloperidol-induced catalepsy, and pole climb avoidance test comparable to the standard drug trihexyphenidyl. Our study indicates that $M$. esculenta could be used as an alternative/adjuvant drug in preventing and treating symptoms of psychotic conditions. However, it requires further preclinical and clinical studies to prove it.

\section{REFERENCES}

Bhatt, I. D., Rawal, R., \& Dhar, U. (2000). "The Availability, Fruit Yield, and Harvest of Myrica Esculenta in Kumaun (West Himalaya), India." Mountain Research and Development, 20(2), 146-153. https://doi.org/10.1659/0276-4741(2000)020[0146:TAF YAH]2.0.CO;2

Brownlee, G., \& Spriggs, T. L. (1965). Estimation of dopamine, noradrenaline, adrenaline and hydroxytryptamine from single rat brains. The Journal of pharmacy and pharmacology, 17(7), 429-433. https:// doi.org/10.1111/j.2042-7158.1965.tb07698.x

Erbaş, O., Akseki, H. S., Eliküçük, B., \& Taşkıran, D. (2013). Antipsychotic-Like Effect of Trimetazidine in a Rodent Model. The Scientific World Journal, 2013, 686304. https://doi.org/10.1155/2013/686304

Jain, B. N., Jain, V. K., \& Shete, A. (2010). Antipsychotic Activity of Aqueous Ethanolic Extract of Tinospora cordifolia in Amphetamine Challenged Mice Model. Journal of advanced pharmaceutical technology \& research, 1(1), 30-33.

Kabra, A., Martins, N., Sharma, R., Kabra, R., \& Baghel, U. S. (2019a). Myrica esculenta Buch.-Ham. ex D. Don: A Natural Source for Health Promotion and Disease Prevention. Plants (Basel, Switzerland), 8(6), 149. https://doi.org/10.3390/plants8060149

Kabra, A., Sharma, R., Singla, S., Kabra, R., \& Baghel, U. S. (2019b). Pharmacognostic characterization of Myrica esculenta leaves. Journal of Ayurveda and integrative medicine, 10(1), 18-24. https://doi.org/10.1016/j. jaim.2017.07.012

Kabra, A., Sharma, R., Hano, C., Kabra, R., Martins, N., \& Baghel, U. S. (2019c). Phytochemical Composition, Antioxidant, and Antimicrobial Attributes of Different Solvent Extracts from Myrica esculenta Buch.-Ham. ex. D. Don Leaves. Biomolecules, 9(8), 357. https://doi. org/10.3390/biom 9080357

Kapur, S., \& Seeman, P. (2002). NMDA Receptor Antagonists Ketamine and PCP Have Direct Effects on the Dopamine D(2) and Serotonin 5-HT(2) ReceptorsImplications for Models of Schizophrenia. Molecular psychiatry, 7(8), 837-844. https://doi.org/10.1038/ sj.mp.4001093 
Kamila, S., Madhav, N. V. S., \& Sarkar, C. N. (2015). "Amnesic Potentiality of Diazepam At Low Dose on Administration via Transcranial Route in Rodents." International Journal of Pharmaceutical Sciences and Research, 6(1), 300-307. http://dx.doi.org/10.13040/ IJPSR.0975-8232.6(1).300-07

Nishchal, B. S., Rai, S., Prabhu, M. N., Ullal, S. D., Rajeswari, S., \& Gopalakrishna, H. N. (2014). Effect of Tribulus terrestris on Haloperidol-induced Catalepsy in Mice. Indian journal of pharmaceutical sciences, 76(6), 564-567.

Polydoro, M., Schröder, N., Lima, M. N., Caldana, F., Laranja, D. C., Bromberg, E., Roesler, R., Quevedo, J., Moreira, J. C., \& Dal-Pizzol, F. (2004). Haloperidoland Clozapine-Induced Oxidative Stress in the Rat Brain. Pharmacology, biochemistry, and behavior, 78(4), 751-756. https://doi.org/10.1016/j.pbb.2004.05.018

Protais, P., Costentin, J., \& Schwartz, J. C. (1976). Climbing Behavior Induced by Apomorphine in Mice: A Simple Test for the Study of Dopamine Receptors in Striatum. Psychopharmacology, 50(1), 1-6. https://doi. org/10.1007/BF00634146

Sahoo, S. K., Sahoo, H. B., Priyadarshini, D., Soundarya, G., Kumar, C. K., \& Rani, K. U. (2016). Antiulcer Activity of Ethanolic Extract of Salvadora indica (W.) Leaves on Albino Rats. Journal of clinical and diagnostic research: JCDR, 10(9), FF07-FF10.

Sanberg P. R. (1980). Haloperidol-Induced Catalepsy is Mediated by Postsynaptic Dopamine Receptors. Nature, 284(5755), 472-473. https://doi. org/10.1038/284472a0
Sapkota, B., Prakash K., Chandra, \& Jain, V. (2020). "Preliminary Phytochemical Screening and Quantitative Analysis of Citrus Maxima (Brum.) Leaves Extract." International Journal of Research in Pharmacology \& Pharmacotherapeutics, 9(1): 100-106.

Sood,P., \& Shri, R..(2018). “AReview on Ethnomedicinal, Phytochemical and Pharmacological Aspects of Myrica Esculenta." Indian Journal of Pharmaceutical Sciences, 80(1), 02-13. https://doi.org/10.4172/pharmaceuticalsciences. 1000325

Srivastava, B., Sharma, V. C., Pant, P., Pandey, N. K., \& Jadhav, A. D. (2016). Evaluation for Substitution of Stem Bark with Small Branches of Myrica esculenta for Medicinal Use - A Comparative Phytochemical Study. Journal of Ayurveda and integrative medicine, 7(4), 218-223. https://doi.org/10.1016/j. jaim.2016.08.004

Surveswaran, S., Cai, Y., Corke, H. \& Sun, M. (2007). "Systematic Evaluation of Natural Phenolic Antioxidants from 133 Indian Medicinal Plants." Food Chemistry, 102(3), 938-953. https://doi.org/10.1016/j. foodchem.2006.06.033

Welch, B. L., \& Welch, A. S. (1969). Aggression and The Biogenic Amine Neurohumors. In: Aggressive Behavior. Garattini, S., Sigg., E. B. (eds). Amsterdam: Excerpta Medica. 